\title{
BROOKS/JACKSON'S LEVEL CLEOPATRA: PRODUCTION AND RECEPTION
}

José Roberto O’Shea

The influence which current views on dramatic theory and technique have exercised upon theatrical productions has long been the object of scholarly inquiry. Peter Brook's The Empty Space (1968; rpt. 1990), for instance, can be a helpful tool in the study of Brook's own 1978 Royal Shakespeare Company production of Antony and Cleopatra, with Glenda Jackson and Alan Howard in the title roles. The production followed by eight years the now legendary "circus" Midsummer Night's Dream which Brook had staged for the RSC in 1970, and reviewers were virtually unanimous in praising the production's innovative, swiftly-paced set. Nevertheless, many objected that Brook's deromanticized reading "reduced" the stature of Jackson's Cleopatra and Howard's Antony, thus undermining their tragic fall. Accounting for production decisions, mainly set design and staging, and focusing upon Brook's/Jackson's representation of Cleopatra, I argue that Brook's rendering is a radical interpretation, mainly in the light of his own views as expressed in The Empty Space (TES), especially in terms of his discussion of Shakespeare mixing outer and inner worlds-" Rough" and "Holy Theatre" - and his attempt to circumvent "Deadly Theatre". The argument is counterpointed throughout with commented illustrations of the production's critical reception.

\begin{tabular}{|l|l|l|l|l|}
\hline Ilha do Desterro & Florianópolis & $n^{\circ} 39$ & p.095-112 & jul./dez. 2000 \\
\hline
\end{tabular}


When The Empty Space was first published, i.e., in 1968, Peter Brook was a producer and director of the Royal Shakespeare Company in Britain and founder of the International Centre of Theatre Research in Paris. ${ }^{1}$ Based upon a series of four lectures originally delivered in 1965 by Brook at four British universities under the title "The Empty Space: The Theatre Today", the book advances Brook's views on the making of drama, as he held them at the end of the 1960s. By 1980, The Empty Space, in the words of Richard Proudfoot, was "a bible of experimental theatre in England" (158). The book is organized into four chapters, namely, "The Deadly Theatre", "The Holy Theatre", "The Rough Theatre", and "The Immediate Theatre".

Given Brook's distinction of the four meanings of the word "theatre", in a general sense, "Deadly Theatre" means "bad theatre", i.e., theatre that is not concerned with formal and thematic challenge, theatre that is overly concerned with being "classical", therefore, "dull". The setback, Brook argues, is that this is the form of theatre we see most often. It is also closely linked to bad commercial theatre. Furthermore, Brook reminds us, "Deadly Theatre takes easily to Shakespeare". In Brook's words, "nowhere does the Deadly Theatre install itself so securely, so comfortably and so slyly as in the works of William Shakespeare" (TES 12). The problem with "dead" productions of Shakespeare is that although we see his plays done by good actors in what seems like the proper way-they look lively and colourful, there is music and everyone is all dressed up...

...Yet secretly we find it excruciatingly boring" (TES 12). Lacking intensity, such "dead" productions, Brook submits, depend upon a "deadly spectator" the scholar who comes out of the theatre "smiling because nothing has distracted him from trying over and confirming his pet theories to himself" (TES12-13).

But how exactly can a director avoid Deadly Theatre? According to Brook, a sound starting point is to stay clear of the pitfalls caused by the concern with catering to values such as "classica", "timeless": 
It is vain to pretend that the words we apply to classical plays like 'musica', 'poetic', 'larger than life', 'noble', 'heroic', 'romantic', have any absolute meaning. [Such words] are the reflections of a critical attitude of a particular period, and to attempt to build a performance today to conform to these canons is the most certain road to deadly theatre-deadly theatre of a respectability that makes it pass as living truth.

Certainly, "conforming" solutions engender the appearance of "respectability" that makes a "classic" production pass as "living truth", and that, at the same time, Brook suggests, fossilizes the theatrical experience. Brook sounds the warning that deadliness always entails repetition. The deadly director uses old formulae, old, "tested" methods, old effects, stock beginnings and ends to scenes. Moreover, in a deadly production, repetition applies not only to direction but to everything else: design, wardrobe, music etc. (TES44). The consequences of Deadly Theatre are obvious: the audience is let down and theatre attendance drops.

Surely, there is no success formula in theatre, but, for Peter Brook, one sure way to start is to maintain a critical, open-minded thematic stance. Whereas Deadly Theatre approaches the classics "from the viewpoint that somewhere, someone has found out and defined how the play should be done", by contrast, "[i]n a living theatre, we would each day approach the rehearsal putting yesterday's discoveries to the test, ready to believe that the true play has once again escaped us" (TES 17). ${ }^{2}$ A living theatre is characterized by challenge, by experimentation, exposure, "artistic risk" (TES 21-22).

Given his horror of Deadly Theatre, as a director, Brook tries to take certain precautions. First and foremost, the director must demythicize the text. When he hears a director speaking of "serving the author, of letting the play speak for itself", Brook's suspicions "are aroused". For Brook, if you simply "let a play speak, it may not make a sound". For a play to speak at all, the director "must conjure its sound 
from it" (my emphasis). Drawing "sound" from a play "demands ... deliberate actions". The end result may entail simplicity, but "setting out to be 'simple' can be quite negative, an easy evasion of the exacting steps to the simple answer" (TES 43). Second, the director must demythicize his/her own role. The director "does not ask to be God and yet his role implies it", says Brook. There is an "instinctive conspiracy of the actors to make him arbiter, because an arbiter is so desperately wanted all the time". Yet, this arbiter is "an imposter", "a guide" who does not know his/her own territory, who learns the route as he/she goes. If the director is not aware of this situation, and hopes for the best, when it is the worst that he/ she needs to face at all times, "[d] eadliness often lies in wait" (TES 44). Third, again, the director has to avoid repetition, old formulae, has to challenge conditioned expectations (TES 44). For Brook, the whole effort on the part of theatre people is to turn deadly theatre into living theatre.

At the base of the concept of "Holy Theatre" is the "notion that the stage is a place where the invisible can appear" (TES47). For Brook, the phrase "Holy Theatre" is an abbreviation for "The Theatre of the Invisible-Made-Visible". The notion goes way back in art history, for, as Brook aptly reminds us, to comprehend the visibility of the invisible is the purpose of "Holy Art"; hence, the maxim: "[a] holy theatre not only presents the nvisible but also offers conditions that make its perception possible" (TES 63).

Brook traces his notion of Holy Theatre to Antoine Artaud's Theatre of Cruelty, a theatre in which ritual is valued above all else, a theatre "more violent, less rational, more extreme, less verbal, more dangerous" (TES61). Artaud's was a "Holy Theatre", Brook says, "working like the plague, by intoxication, by infection, by analogy, by magic; a theatre in which the play, the event itself, stands in place of a text" (TES 55), a theatre that shocks and surprises, rendering the spectator "more alert, more awake" (TES 62), Brook concludes.

Generally speaking, Rough Theatre is "popular theatre", i.e., close to the people, a theatre of "[s]alt, sweat, noise, smell"--the one which 
"always saves the day" (TES 73). Historically such theatre has taken many forms. It has been housed outside theaters, on carts, on wagons, on trestles, with audiences that stand, drink, sit around tables, joining in the action. Rough-or popular-Theatre takes on a "socially liberating role", for, by nature, it is "anti-authoritarian, anti-traditional, anti-pomp, anti-pretence" (TES 76). ${ }^{3}$

The phrase "Immediate Theatre" encapsulates the "form of a theatre" which Peter Brook recommends, a theatre that is up-to-date (TES 107) and that, at the same time, combines elements of the Holy and the Rough. The notion is clearly akin to what Brook has called "Living Theatre", a concept, we recall, set in opposition to "Deadly Theatre".

But how does Shakespeare's dramaturgy fare in all this? Given Brook's classification, Shakespeare's theatre presents a balanced, "conscious mingling" of Holy and Rough Theatre (TES 98). For Brook, Shakespeare's "aim continually is holy, metaphysical, yet he never makes the mistake of staying too long on the highest plane" (TES 69), for in Shakespeare, "the introspection and the metaphysics soften nothing" (TES 96). ${ }^{4}$ It is "through the unreconciled opposition of Rough and Holy", Brook submits, "that we get the disturbing and unforgettable impressions of his plays" (TES 96).

In The Empty Space, published, I stress, ten years before the RSC production which is the focus of the present paper, Peter Brook is already impatient with the official grandeur that often goes with producing a play for the most celebrated of all Shakespearean companies. In fact, he complains that when he first came to Stratford in 1945 "every conceivable value was buried in deadly sentimentality and complacent worthiness - a traditionalism approved largely by town, scholar and Press" (TES 51). ${ }^{5}$ Thus, to avoid what he has called "Deadly Theatre", Peter Brook constructs a production of Shakespeare's Antony and Cleopatra that, at once, advances a reading of the tragedy that challenges "pedagogical" (TES 86), traditional renderings, emphasizing personal relations rather than public spectacle, and supports such 
reading by a spare, simple set and by the presentation of a vigorous and witty Cleopatra, in the words of one critic, "the liberated woman as the Egyptian Queen" (Watters 27). ${ }^{6}$

Brook's Antony and Cleopatra opened at the Royal Shakespeare Theatre on 4 October 1978 (Press Night October 10). Brook's return to Stratford in 1978, after an absence of eight years, aroused much expectation of a radical, landmark production in the class of his King Lear (1962) and A Midsummer Night's Dream (1970). Robert Cushman, of the Observer, sums up the excitement around Brook's come-back: "Mr. Brook is now generally felt to have a historic function at Stratford: about once a decade, he arrives and changes everything". ?

Students of Peter Brook's work have often pointed out that his approach stems from the pursuit of an assumed "hidden play", a sub-text which is to be discovered and revealed by director and actors (Proudfoot 164). Known for not expressing himself in theatre programs, lest dogmatism on paper is too often weakly realized in performance, Brook reveals, in an interview with John Higgins, some of his thematic concerns in Antony and Cleopatra. He affirms that one of his aims in directing "Antony" was "to correct a few misunderstandings" the main one being "that it is a spectacular play". For Brook, Shakespeare wrote "scenes of intimate behaviour". And he adds, "[t]here is no pageantry. Everything concerns personal relationships; people, including those with famous names, are introduced in closeup..." (Times 18 Oct. 1978, qtd. from Shakespeare Criticism 17: 65). ${ }^{8}$

Brook's level, unromanticized (Shakespeare Criticism 17: 64, 71) understanding of the Antony-and-Cleopatra story took him to devise a production that seemed intimate and, at once, surprisingly dispassionate. ${ }^{9}$ Writing for the Times, Irving Wardle points out that Brook's production "deliberately forfeits any aspirations to the heroic", and that he presents a Cleopatra incapable of love---in a reversal of the traditional treatment of the drama. Brook wants to get rid of "the old heroic myths" and proposes a "demystified portrait of the lovers" (Watters 27). He is, in fact, seeking a revisionist perspective on the affair, previously considered grand---one for which the world was 
"well-lost"--, but which he now "reveals and indulgent and immature" (Elsom 72).

Certainly set design creates a framework where thematic interpretation can be enacted. No doubt, in an elaborate set, the acting can be economical, because the set (as well as costume) is already advancing characterization and performance. Conversely, in a sparse set, the acting has to be more bountiful, more expressive, in order to bear characterization and performance. Sure enough, for Peter Brook, set can either make or break a production. "I have often found", he says, "that the set is the geometry of the eventual play, so that a wrong set makes many scenes impossible to play, and even destroys many possibilities for the actors" (TES 113). Moreover, in terms of set design and costumes, Brook is not worried about reproducing "period" (TES 115); in fact, he depends on creativity, on sets (as well as on costumes) that are not obtrusive.

Brook, in fact, reminds us that we have all become aware that the absence of scenery in the Elizabethan theatre was one of its greatest freedoms. The stage was, of course, just a place, with some doors, which enabled the dramatist to carry the spectator along an "unlimited succession of illusions, covering, if he chose, the entire physical world". This "empty stage" not only "allowed the playwright to roam the world, it also allowed him free passage from the world of action to the world of inner impressions" (TES 97). As we shall see in a moment, this free, "empty stage", which smoothes transitions from outside to inner worlds, is precisely the space in which Brook will set his Antony and Cleopatra. ${ }^{10}$

Analyzing this production's set we see that the emphasis lies on the "personal", rather than on the "public". Indeed, to accommodate Brook's small, intimate play, within an uncut production that ran for 3 $3 / 4$ hours with the interval, Sally Jacobs designed a spare, semicircular ring of four translucent plastic panels, connected side by side by movable trestles. Jacobs' innovative set was unanimously praised by critics-as "expressive", "swift", "non-committal", "antiseptic" (Shakespeare Criticism 17: 64, 66; Wardle; Say)_facilitating the staging of this play's formidable scope: 42 scenes, 25 locales, sprawling into 
three continents. ${ }^{11}$ Hence, the clever, swift, "empty-space" set is a room in Cleopatra's palace one moment, and the battle field near Actium the next.

Echoing Brook's reminder as to the great freedom which the absence of scenery imparted onto the Elizabethan stage, Jacobs declares, in an interview given two days after the play opened at Stratford, that she indeed had Elizabethan theaters in mind when she devised the sparse set for Brook's Antony (Proudfoot 175). In the same interview, Jacobs speaks about her purpose as the production's set designer:

... to create the right sort of intimate space for the play to happen against a background, an ambiguous background. A place where one could always be aware of the outside world affecting the domestic space-and to relate these. Which is why it's a half-seen world, semi-transparent, with many ways of coming in and going out of it.... (Proudfoot 176)

Examining the production promptbook, ${ }_{1}^{12}$ we see that characters indeed entered and exited between the panels, beyond and through which spectators could catch shadowy glimpses of the world of actionsoldiers, attendants, messengers etc. Hence, the private world of the protagonists was kept in focus downstage, while the public world was dimly visible upstage. Occasionally, the outside world intruded on the paneled inner space. The Battle of Actium was represented economically and off stage, by the sounds of waves and fighting. At the beginning of Act III, during an attack, in an Artaudian move, soldiers upstage spattered the panels with splashes of "blood", creating a new backdrop for the second half of the play. The interesting point, of course, is that, looking through the panels, the audience "shared the world view of the protagonists, to whom [the] larger scene appeared unreal (Lamb 175).

Rosemary Say caught on the Elizabethan quality of the set, one that makes fair demands on the imagination of spectators: "we must make use of our own imagination-as Shakespeare originally intended-to conjure up the different worlds of Rome and Egypt in 40 
B.C." Such "austere surroundings", say rightly argues, lead us "without diversion or novelties to watch the downfall of a great soldier. ..".

Clearly downplaying the "grandeur" of Rome and Egypt, the sparse stage was furnished simply with a few cushions, benches, stools, floor mats, and carpets. Brook had a dun-colored carpet raised, "to tip the revellers in Pompey's galley into a drunken sprawl" (Elsom 71); or, even more daringly, for Cleopatra's monument, he had nothing but an inviting, plain red carpet appear hanging and, the suggestion made, lowered to the unraised stage floor (Sunday Times 15 Oct. 1978; Trewin 153). Notoriously difficult, the monument scene became the ultimate test to Jacob's suggestive set. Robert Cushman, of the Observer, wrote:

The set proves itself in the notoriously difficult monument scenes; with no split-level pretenses the dying Antony can simply be hauled horizontally to Cleopatra wrapped in her and her women's scarves.

The promptbook makes it clear that Brook valued simplicity and shunned spectacle throughout the production. In Act 1, at "Look where they come" (i. 10), and at "Behold and see" (i. 13), for instance, Antony and Cleopatra's state entrance has no pomp, and deserves no change of lighting. For her death scene, the red carpet turned into "monument" was lowered, cleverly picking up the red of the "blood" splashed panels. And, although the promptbook establishes "Sits on throne" right before Cleopatra invites the asp to her lap, saying "Come, thou/ mortal wretch" (V.ii.302), reviewers have indicated that such "throne" was, in fact, a brass stool.

To make event stand in place of text, and implement shock and surprise--therefore, moving toward Holy Theatre--, Brook included yet another Theatre of Cruelty gesture. In the Folio, the revelry on Pompey's galley is followed by a brief scene in which Ventidius enters with the body of Pacorus, son of the defeated Parthian King. Altering a Folio stage direction, the promptbook indicates that Brook had Pacorus killed 
on stage, in the words of one reviewer, "the butchery to be contrasted with the Bacchanal" (Sunday Times 15 Oct. 1978). ${ }^{13}$

Besides a clever set design, Brooks depends on an unorthodox Cleopatra to get his "non-pedagogical" message across. In an interview, Glenda Jackson corroborates Peter Brook's view of Shakespeare's Antony and Cleopatra. Jackson saw the play not as an epic, but as a story about "people ['people', not' lovers', mind you] acting out their lives in private rooms" (Observer 8 Oct. 1978).

Appraising Jackson's work by means of its critical reception, we see that positive reviews came mostly from critics who seemed more open to a new representation of Cleopatra. Jackson's Cleopatra was seen as Brook's careful attempt to avoid clichés and pursue new readings of the character. Jackson's is no "bewildering Egyptian temptress" - and no "beauty" either. Refusing to play the part "on the level of Cleopatra's attractiveness" (Seaton), Jackson constructs a determined woman (rather than flighty), "mannish, with short-cropped [red] hair (rather than conventionally sexy)" (Elsom 72). ${ }^{14}$ Between rehearsals, in a partisan feminist stance, Jackson reportedly said: "You always suffer anyway from measuring up to what is considered to be attractive and desirable in a woman-far less, of course, than is ever demanded of a man" (Seaton). Now, if this Cleopatra does not operate on the level of beauty, for one thing, she is close to Plutarch's. And, like Plutarch's, she must depend more on personal charm and intelligence than on beauty to cause Antony to "lose the world" for her.

As with Janet Suzman in Trevor Nurm's 1972 RSC production, Glenda Jackson was seen to portray a Cleopatra of "considerable wit and authority". Jackson's Cleopatra was received as "commanding", "versatile", "impressive" and praised for "wit, power, and intelligence". And, again like Suzman's, Jackson's Cleopatra presents detached, sardonic feelings toward Antony, and does not seem to realize her love for him until after he is dead (Shulman).

Again like Suzman's, this Cleopatra was fierce and vigorous. Looking at the promptbook, we see that she threw a knife after the messenger, and managed to haul Antony over to her side on the 
"monument". In the words of Tamie Watters, Cleopatra was here represented as "an imperious Egyptian cat with ears protruding through her short hair" (27). For Eileen Blumenthal, this Cleopatra is "no sex kitten: she is a dynamo....

Nor is she a lovestruck Juliet, but an experienced and mature woman... who knows how to manipulate, demand, and cajole her way" $(111) .{ }^{15}$

As to negative reviews, on the whole, these express purists' complaints, particularly in terms of this Cleopatra's alleged lack of "passion", "majesty", "tragic fatalism", "pathos". Over and over, Jackson's Cleopatra was considered "asexual", blamed for "lacking in vulnerability and passion" (SC 17:64), lacking "overwhelming passion" (Blumenthal 112). ${ }^{16}$

Writing for Newsweek, Jack Kroll recognizes Jackson's Cleopatra as "a brilliant image and a cleaving force", but laments that she is "too controlled to be the iridescent wanton that enslaved the greatest of world leaders" (66). Ray Seaton complains that the attachment between Antony and Cleopatra is "stated more than rendered in human terms. One simply has to take their love for granted", he says.

Jackson's/Brook's Cleopatra was also charged with being "too prosaic" a charge, by the way, which Brook himself rebuked in an interview with John Higgins:

[Jackson's detractors] have wrongly been looking for the images Claudette Colbert and Gaby Pascal placed on her.... It should be remembered that Cleopatra in the flesh has nothing to do with the Cleopatra Enobarbus describes. Shakespeare was not covering her in mystery. The reverse is the case, because he makes her speak in the most direct way. (Times 18 Oct. P. 11)

Besides, Jackson's Cleopatra was seen as "unbelievable". "This [mannish] Cleopatra", John Elsom says, "would not have run, before 
Antony, from the sea battle. She would have stayed and fought and nagged him afterwards" (72).

Reviewing the "refined and adjusted" production of Antony and Cleopatra which Brook took to the Aldwych in London in July 1979 for a limited season, the New York Times critic saw Glenda Jackson as "a difficult choice for Cleopatra". There is, "at first glance", he says, "something brisk and suburban about her". For him, she lacked the "native seductiveness that we expect to see". Yet, he admits that Jackson "fashions a performance that grows notably as the play progresses" and that at the moment when things begin to go awry, "she becomes the image of a woman fighting a battle whose end she cannot foresee" (Eder 3). And, again assessing the Aldwych production, another critic found Jackson's Cleopatra "intelligent and vivacious but strangely asexual", and lamented that "[t]he textual images which associate Cleopatra with the earth and fertility were ignored" (Kennedy 423).

Now, as it seems, in terms of critical reception, Peter Brook's return to Stratford with his Antony and Cleopatra, to a certain extent, failed to cause the impact expected. ${ }^{17}$ Writing for the Shakespeare Quarterly the following spring, J. C. Trewin seems sorry that the production's opening night "came and went without the tension and final overwhelming shout of applause that had marked the 1970 premiere of A Midsummer Night's Dream" (151). ${ }^{18}$ The 1978 RSC revival was, in the words of Margaret Lamb, "austere, fast-paced, scaled down, with little emphasis on-or perhaps faith in - the possibilities of tragic sexual passion" (173). However, looking back, we see that, on the whole, the production was praised, although it failed to arouse great enthusiasm with those who expected a more radical rendering. Some critics admitted that Brook succeeded in avoiding clichés but failed to offer a whole new alternative to them, but only "half a dozen creative shifts of emphasis" (Treglown 18). Some felt that the intense focus on the relationship between Antony and Cleopatra made the love affair seem "self-indulgent" and "narcissistic". ${ }^{19}$ Brook's dispassionate reading did not go well with those 
who felt that if they could not "believe in the love affair, then its consequences seem incredible and the story falls apart" (Elsom 72).

Perhaps, Brook's Antony was not as sensational as his Dream, or as experimental as the work he was doing at that time with his theatre research group in Paris. Perhaps, the production lacked the politicized dimension which so many expected to find. But examining the promptbook, we see that Brook tries hard-and manages-to avoid cliché renderings of form and content and, at the same time, generates "intensity", by delivering the opposite of what might be expected. In TES Brook insists that Shakespeare mixes outer and inner world, Rough and Holy Theatres, and Brook's Antony and Cleopatra does mix outside and inside worlds, in the metaphysical sense. After all, this is a version of the famous story that takes place mostly in private, almost a "chamber version of the play" (Lamb 174). However, the mixing, or overlapping, of outside and inside worlds is physically evident in Sally Jacobs' set design. With this new Antony, Brook emphasizes personal relations, not public spectacle, without falling back on a romanticized reading of the legendary love affair. Besides, Shakespeare's mixing of Rough and Holy Theatre is also present in this Brook's Artaudian moves. Peter Brook wants to circumvent Deadly Theatre, i.e., one that is not concerned with thematic challenge. And, despite contrary reviews by nostalgic purists, Brook's/Jackson's Cleopatra will, I believe, produce the disturbing, unforgettable impression the directors aims for. Could it not be that this determined, emancipated Cleopatra, whose overt lack of sexuality so annoyed purists, had the intense, if controlled, gut-felt sexuality that did not express itself in cliché, pin-up like, purrs and hisses?

\section{Notes}

1 For a discussion of Brook's experience with this multinational Theatre Research Centre see Roose-Evans's book under bibliography below, especially chapter 18. 
2 Brook's "progressive" rehearsal methods, and extended rehearsal time, have been widely commented on and discussed by scholars, theatre people, and press. Essentially, all rehearsal activity aimed at "breaking down theatrical clichés and actors' habits" (Proudfoot 158, 171, 174).

3 We must be reminded that all surviving records, descriptions, and commentary indicate that, to a great extent, Elizabethan theatre was "rough", in the sense Brook defines here.

4 Surely, Brook is right. We need only to remind ourselves of Shakespeare's consistent, ubiquitous use of comic relief in the tragedies.

5 Brook's work for the RSC has been competently traced by Richard Proudfoot in the article cited below.

6 Newspaper reviews quoted in this paper were consulted in the scrapbooks housed at the Shakespeare Centre and the Shakespeare Institute, Stratford-upon-Avon (not all are dated or have page numbers indicated).

7 The effects of the high expectations on the critical reception of the production deserves further investigation, especially in the light of Susan Bennett's Theatre Audiences: A Theory of Production and Reception (1990 Routledge: rpt. 1994), a book which Margarida Rauen brought to my attention in conversation..

8 I agree. The "barge she sat in" pageantry, for instance, is not depicted on stage; Shakespeare invites us to imagine the scene through the eyes of Enobarbus.

9 As has often been stressed, Peter Brook's views on Antony and Cleopatra as an intimate play depend much on Ian Kott's. In Shakespeare, Our Contemporary, Kott states: "In Antony and Cleopatra, the world is little. It seems much smaller than in Plutarch. It is narrow and everything seems to be nearer" (173).

10 The concern with "period", especially in terms of costumes, was very evident in the previous RSC Antony and Cleopatra, i.e., Trevor Nunn's “Tutankhamen”, 1972 production, which, by the way, Sally Jacobs acknowledges as "academically very accurate" (Proudfoot 175).

11 In fact, the spare, empty-space set for the 1978 Antony followed the style of previous RSC productions by Peter Brook. The 1950 Measure for Measure, for instance, had nothing but a double range of lofty arches, which might represent the 
convent or a street at night, or which, in a moment, with the aid of light and props, could become the courtroom or the prison cells (Proudfoot 159). Sally Jacobs' stage for the 1972 Dream was "white-walled and empty", plus, of course, the famous two trapezes (Proudfoot 167).

12 A photocopy of the production's promptbook was kindly made available to me by the staff of The Shakespeare Centre in Stratford-upon-Avon. The text Brook used for the play was Emrys Jones's New Penguin, which had come out he year before (1977).

13 As Margaret Lamb perceptively points out, Artaud's Theatre of Cruelty had helped Brook "probe the roots of suffering" in the 1955 Titus Andronicus. In Antony, the "Artaudian interpolation" evokes Brook's much discussed cut in his King Lear(1962), where he omitted the servants' objections to Gloucester's blinding $(173-75)$.

14 However, regarding Jackson's looks and gestures, Milton Shulman advances what seems to me the most valid critique of this Cleopatra. Shulman cogently laments that Jackson is "so stubbornly Anglo-Saxon that it makes nonsense of genetics to suggest she could ever project the essence of a dark-haired African Queen".

15 Current headlines illustrate that some critics caught on Brook's revisionist attempts: "A New View of Ritual Love" (Helen Reid, Western Daily Press); "A Powerful Production" (Norah Lewis, Birmingham Evening Mail); "Setting the Nile on Fire" (Peter McGarry, Coventry Evening Telegraph).

16 Likewise, some of the headlines of the reviews that followed the opening night at Stratford are exemplary in voicing the let down: "Cleopatra loses most of her passion" (Ray Seaton, Wolverhampton Express); "Cold Cleo" (Milton Shulman, Evening Standard); "Finite Variety" (Robert Cushman, Observer).

17 Tamie Watters stood as an important exception (see bibliography below).

18 I am again reminded of Susan Bennett's arguments, this time her discussion of post-performance let downs.

19 See, for instance, John Elsom, The Listener, vol. 100, No. 2582, pp. 571-72. 


\section{Bibliography}

Barker, Felix. "Carry on up the Nile, by Shakespeare". Evening News 11 Oct. 1978.

Bennett, Susan. Theatre Audiences: A Theory of Production and Reception. London: Routledge, 1990.

Blumenthal, Eileen. "Toils of Grace". Village Voice, v. 23, no. 48. 27 Nov. 1978. pp. 111-12.

Brook, Peter. The Empty Space (1968). London: Penguin, 1990. . Interview with John Higgins. Times, London 18 Oct. 1978. p. 11.

Cushman, Robert. Observer 15 Oct. 1978.

Durman, David. “Glenda Jackson says'No'to Newcastle". Newcastle Journal16 Oct. 1978.

Eder, Richard. "A Lucid' Antony and Cleopatra'from Peter Brook". New York Times, section 2. 19 Aug. 1979. p.3.

Elsom, John. "An Indulgent Affair". The Listener, v. 100, no. 2582. 19 Oct. 1978. pp. 571-72.

Harner, Mary. Signs of Cleopatra: History, Politics, Representation. London and New York: Routledge, 1993.

Hughes-Hallet, Lucy. Cleopatra: Histories, Dreams and Distortions. London: Bloomsbury, 1989.

Kennedy, Dennis. "Antony and Cleopatra". Theatre Journal, v. 3 1, no. 3. Oct. 1979. pp. $420-23$.

Kott, Ian. Shakespeare Our Contemporary. Garden City, NY: Doubleday, 1964.

Kroll, Jack. "Oh, To Be in England". Newsweek, v. 92, no. 22. 27 Oct. 1978. pp. 65-6, 69.

Lamb, Margaret. Antony and Cleopatra on the English Stage. London and Toronto: Associated University Presses, 1980. 
Lewis, Norah. "A powerful production". Birmingham Evening Mail 11 Oct. 1978.

McGarry, Peter. "Setting the Nile on fire Coventry Evening Telegraph 11 oct. 1978.

Observer 8 Oct. 1978.

Parsons, Gordon. 'Anthony and Cleopatra". Morning Star 12 oct. 1978.

Pavis, Patrice. Theatre at the Crossroads of Culture. Trans. Loren Kruger. London: Routledge, 1992.

Proudfoot, Richard. "Peter Brook and Shakespeare". Themes in Drama, ed. James Redmond, v. 2. (1980) pp. 157-89.

Reid, Helen. "A new view of ritual love". Western Daily Press 11 Oct. 1978.

Roose-Evans, James. Experimental Theatre: From Stanilavsky to Peter Brook [1970]. Fourth edition, revised and updated. London: Routledge, 1989.

Say, Rosemary. "Antony minus the majesty". Sunday Telegraph 15 Oct. 1978.

Shakespearean Criticism v. 17. pp. 64-74.

Shulman, Milton. "Cold Cleo". Evening Standard 11 Oct. 1978.

Sunday Times 15 Oct. 1978.

Tinker, Jack. "Glenda, the majestic queen of the Nile—but with just a dash of Surbiton" Daily Mail 11 Oct. 1978.

Treglown, Jeremy. "Antony and Cleopatra". Plays and Players, v. 26, no. 3. Dec. 1978. p. 18.

Trewin, J. C. "Antony and Cleopatra at the Royal Shakespeare Theatre, Stratford" Birmingham Post 11 Oct. 1978.

. Peter Brook: a Biography. London: Macdonald \& Co., 1971. $151-58$. "Shakespeare in Britain". Shakespeare Quarterly, v. 30, nº 2. Spring (1979): pp. 
112 José Roberto O'Shea

Wardle, Irving. 'Antony and Cleopatra': Royal Shakespeare". Times, London, 11 Oct. 1978, p.9.

Watters, Tamie. "Brook Continues His Shakespearean Surprises". Christian Science Monitor 17 Nov. 1978. p. 27.

Young, B.A. 'Antony and Cleopatra". Financial Times 12 oct. 1978. 